\title{
China-Pakistan economic corridor (CPEC) issues/barrier and imperatives of Pakistan and China
}

Muhammad Umer Arshad

Inner Mongolia University

Zhao Haidong

Inner Mongolia University

\section{Recommended Citation}

Arshad, M. U., \& Haidong, Z. (2017). China-Pakistan economic corridor (CPEC) issues/barrier and imperatives of Pakistan and China. International Interdisciplinary Business-Economics Advancement Journal, 2(2), 104-114.

\section{Revisions}

Submission date: Oct. 1, 2016

1st Revision: Feb. 7, 2017

2nd Revision: Feb. 21, 2017

3rd Revision: Mar. 16, 2017

Acceptance: Jun. 6, 2017 


\title{
China-Pakistan Economic Corridor (CPEC) Issues/Barrier and Imperatives of Pakistan and China
}

\author{
Muhammad Umer Arshad ${ }^{1}$ and Zhao Haidong ${ }^{2}$ \\ Department of Economic, \\ Inner Mongolia University, Hohhot, China, \\ ${ }^{1}$ Student.Pak@yahoo.com \\ Economic Department, \\ Inner Mongolia University, Hohhot, China, \\ 2hdzhaoyy@163.com
}

\begin{abstract}
China-Pakistan Economic Corridor (CPEC) is blessing for Pakistan and China. China and Pakistan have best political relations. CPEC is going to boost up the economic relations between both countries. China's participation in the development of Gwadar Port took the international attention. Planning the development of Gwadar port becomes an important content of CPEC. This way Gwadar port has entered into a new development period. Due to their potential impact on the strategic pattern of the Indian Ocean and because of its strategic importance, there is international repercussion, also have other difficulties such as cost, security issues in Pakistan and Power crises and other issues. This paper attempts to explain the challenges, due to security issues, culture difference, energy and political crises in Pakistan, conflict in Baluchistan, and external pressure. Finally, this paper discusses some specific measures of barriers, solutions and suggestions. CPEC will be a game changer on the regional canvas and is expected to bring prosperity and improve quality of life in general to the region and in particular to Pakistan. There is a dire need to take on board all the regional and global players by addressing their concerns for early establishment of CPEC.
\end{abstract}

Keywords: issues and challenges of CPEC, solution for strategic risk at China and Pakistan economic corridor, problems of Gwadar port, barrier for Chinese companies in Pakistan, CPEC

\section{Introduction}

January 2013, Pakistan's government decided to transfer the rights of Gwadar port to Chinese company. February 2013 both parties singed transfer right agreement, In May 2015 Chinese President visited Pakistan after a lapse of 9 years, is to be planted into the annals of China Pakistan relations, with milestone significance of access, visiting time was only 28 hours, but content was very rich, which proposed the construction of China Pakistan Economic Corridor (Raza, 2013). CPEC is another part of One Belt-One Road; worth of this project is 46 billion dollars. Gwadar port is on the Indian Ocean, located in the Arabian Sea, and has natural deep water, Ice free harbor, at the Baluchistan province of Pakistan. Gwadar port is 460 kilometers away from Karachi port, 120 kilometers away from Iran Border, located away from India. Because of Geo strategic location of this port, in 1990 USA had planned to participate in the 
development of Gwadar port, but impede the matter to no avail, affected by various factors. At the beginning of $21^{\text {st }}$ century on Pakistan's request China agreed to help the development of Gwadar port. According to the words of Chinese president XI Jinping, the two countries are presented with a great opportunity to build the China- Pakistan community of common destiny and set a fine example for efforts by China and its neighboring countries, between South Asia and the region of central Asia, Middle East China and Pakistan. CPEC will benefit about 3 billion people in these regions through the inter regional connectivity and economic dividends of its projects. At the same time, it will provide great energy and food security for China.

Under the proposed project, a high-speed railway track will be constructed from Karachi to Peshawar at cost of $\$ 2.8$ billion. Punjab province, east of Pakistan, have the largest population in Pakistan. China Pakistan corridor has number of projects in Punjab province as well, including highways, power stations, rail transportation and other projects. China Pakistan Economic Corridor is not only One road or railway track but it would generate economic activities, jobs, and may following industries are feasible for investor in Baluchistan (a) Port related Facilities (b) Oil (c) Solar Energy (d) Oil and Gas exploration Industry (e) Oil storage , Refinery, Petrochemical related industries (f) Export of minerals \& Live stock (g) wind energy (h) Ship Repairs \& Ship Building (i) Construction of Warehouses \& Storages (j) Beach Industry (k) Good transportation services (l) ferry services between Gwadar, Karachi, and Gulf States (m) freezing and Packing facilities for the fish industries (n) private schools and hospitals (o) electric Power Generation (SATP) tourism Industries \& small producing Unit (q) Investment in Energy sector Particularly renewable energy, LPG (Liquefied petroleum gas) plants etc.

China Pakistan Economic corridor, will directly promote the cooperation and win-win Chinese and Pakistani economy. This will be linked more frequently in the political, military, diplomatic, and other areas, and cultural exchange is too deepening bilateral relations in these areas, has become more and more important. At Present China and Pakistan both have Chinese and Pakistani research centers, have regular contact, and exchange of visits between the students, teachers, journalists, academics, and research staff. Three Confucius colleges and four are under construction, many students and young people are learning Chinese. The communication between both countries is becoming more and more important because of the deepening of understanding.

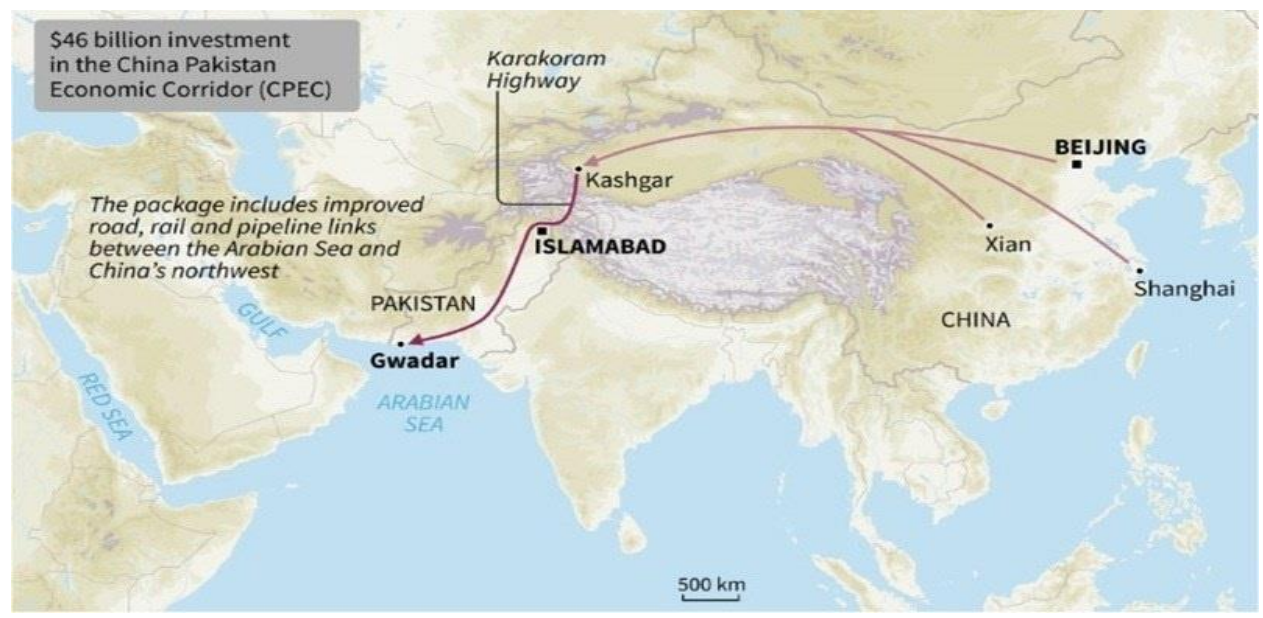

Source: Route of China Pakistan Economic Corridor 
China and Pakistan are all weather strategic partners, both countries have highly mutual trust, mutual respect on each other. Overall friendly situation and strategic view of the relationship between China and Pakistan, therefore it is very easy to carryout policy communication, docking economic development policy for both countries.

\section{Investment Distribution of China Pakistan Economic Corridor}

CPEC is not only a network of roads, highways, railway network but it's a combine package of different projects including long including rail-road network from Kasghar to Gwadar the construction of 12-13 special economic zone along with the corridor and transport, communication sector energy sector investment energy sector and industry sector to people to people cooperation that will fulfill the energy and other requirement of Pakistan. Initially the cost of this project was estimated 18-20 billion dollars then it increased to 32 billion dollars and then now the total investment is $\$ 46$ billion.

CPEC is not only a network of road, highways, rail network but it's a package of different projects that fulfill the energy and other requirement of Pakistan. Total Investment of China is about $\$ 46$ billion. The breakup of CPEC projects portfolio investment is given in following table.

Table 1: The Breakup of CPEC Projects Portfolio Investment

\begin{tabular}{ll}
\hline Name of Projects & Cost Us \$ Million \\
\hline Energy Priority Projects & 33728 \\
Infrastructure & 11636 \\
Gwadar Projects & 792.6 \\
Other Projects & 44 \\
& 46.2006 \\
\hline
\end{tabular}

One of the basic requirements for the economy of Pakistan is energy. Pakistan is facing shortage of electricity since last decade. Due to the load shedding, businesses suffer badly. Due to the high demand of electricity, the energy projects play a vital importance in CPEC projects. Following projects should be completed under CPEC investment plan.

Table 2: Energy Priority Projects

\begin{tabular}{llll}
\hline$\#$ & Name of Project & MW & Cost US \$(m) \\
\hline 1 & Port Qasim Electric Company Coal Fired, 2x660, Sindh & 1320 & 1,980 \\
2 & Sahiwal 2x660MW Coal-fired Power Plant, Punjab & 1320 & 1,600 \\
3 & Engrothar 4x330MW Coal-fired, Thar, Sindh & 1320 & 2,000 \\
& Surface mine in Block II of Thar Coal field, 6.5 metric ton per annum (mtpa), & & 1,470 \\
& Thar Sindh & 300 & 600 \\
4 & Gwadar Coal /LNG / Oil Power Project, Gwadar & 660 & 970 \\
5 & HUBCO coal power plant 1X660 MW, Hub Balochistan & 1320 & 1,600 \\
6 & Rahimyar Khan Coal Power Project, Punjab & & 1,300 \\
7 & SSRL Thar Coal Block 1 - 6.5 metric ton per annum(mpta) Thar, Sindh & 1320 & 2,000 \\
& SSRL 2×660 MW Mine Mouth Power Plant,Sindh & 1000 & 1,350 \\
8 & Quaid-e-Azam 1000MW Solar Park, Bahawalpur, Punjab & 50 & 125 \\
9 & Dawood 50MW wind Farm, Bhambore, Sindh & 100 & 250 \\
10 & UEP 100MW wind Farm, Jhimpir, Sindh & 50 & 134 \\
11 & Sachal 50MW Wind Farm, Jhimpir, Sindh & 870 & 1,802 \\
12 & SukiKinari Hydro power Station, KPK & 720 & 1,420 \\
13 & Karot Hydropower Station, AJK \& Punjab & & \\
\hline
\end{tabular}




\begin{tabular}{llll}
\hline$\#$ & Name of Project & MW & Cost US \$ (m) \\
\hline 14 & Matiari to Lahore Transmission line & & 1,500 \\
15 & Matiari to Faisalabad Transmission line & & 1500 \\
& Actively Promoted Energy Projects & & \\
16 & Gaddani Power Park Project (2×660MW & 1320 & 3960 \\
& Gaddani Power Park Project (Jetty + Infrastructure) & & 1200 \\
17 & HUBCO coal power plant 1X660 MW, Hub Balochistan & 660 & 970 \\
18 & KohalaHydel Project, AJK & 1100 & 2397 \\
19 & Pakistan Wind Farm II 2X50 MW (Jhampir, Thatta, Sindh) & 100 & 150 \\
20 & Thar mine mouth oracle, Thar Sindh & 1320 & 1300 \\
21 & Muzaffargarh Coal Power Project, Punjab & 1320 & 1600 \\
22 & Gas Power Plant 525 MW & 525 & 550 \\
\hline & Total & 16695 & 33728 \\
\hline
\end{tabular}

This section describes the transport infrastructure sector projects. These projects have a capability to reduce the shipping costs and transit time of Chinese imports and exports.

Table 3: Infrastructure Projects

\begin{tabular}{llll}
\hline$\#$ & Project Name & Length Km & Cost US\$(m) \\
\hline Road & & & \\
1 & KKH Phase II (Thakot -Havelian Section) & 118 & 1305 \\
2 & KKH Phase II (Raikot - Islamabad Section) ) & 322 & 2195 \\
3 & Peshawar-Karachi Motorway (Multan-Sukkur Section) & 392 & 2846 \\
4 & Mass Transit in Lahore & & 1600 \\
$\quad \quad$ Rail Sector Projects & & \\
5 & Expansion and reconstruction of existing Line ML-1 & \multirow{2}{*}{1736} & 4650 \\
6 & Havelian Dry port (450 M. Twenty-Foot Equivalent Units) & & 40 \\
\hline$\quad$ Total & 2568 & 11636 \\
\hline
\end{tabular}

In given table, all the Gwadar development related projects are listed. Before completion of CPEC, Gwadar needs adequate infrastructure to fulfil future demands which will generate from the project. Mentioned below are projects for the Gwadar city.

Table 4: Gwadar Projects

\begin{tabular}{lll}
\hline$\#$ & Project Name & Estimated Cost (US\$ M) \\
\hline 1 & East-Bay Expressway & 140.6 \\
2 & Gwadar International Airport & 230.00 \\
3 & Construction of Breakwaters & 123.00 \\
4 & Dredging of berthing areas \& channels & 27 \\
5 & Infrastructure for Free Zone \& EPZs port related industries & 32 \\
6 & Necessary Facilities of Fresh Water Treatment and Supply & 130 \\
7 & Hospital at Gwadar & 100 \\
8 & Technical and Vocational Institute at Gwadar & 10 \\
\hline & Total & 792.6 \\
\hline
\end{tabular}

Source: Rafiq (2016)

\section{Geo Strategic Importance of CPEC}

The provision of China Pakistan Economic Corridor between the interconnected regions can bring prosperity and trade. They bring about investment by foreign as well as local investor that can boost economic engine in geo strategic regions. China Pakistan Economic Corridor has capacity to generate economic revival for Pakistan and prosperity in the western region of China, 
The Geo strategic corridor is beneficial not only for Pak-Sino relations but also for the regional development that will eventually benefit all neighboring countries coming into the connection.

From a geo strategically point of view, Pakistan is located in the northwest of South Asia, connecting the east with India, northeast with China, northwest along with Afghanistan, the west border with Iran, south near to the Arabian Sea, is located in the gateway to South Asia, Central Asia, West Asia, and the Middle East traffic fortress. From a certain point of view, Pakistan has friendly relationship with Chinese. In the area to meet the geo political needs of China, in fact as an important component of China's strategic peripheral, Pakistan has full support of China's peaceful development policy, including the prevention of terrorist extremist in Xinjiang province, Because Pakistan has realized to use its geopolitical position. This framework is based on ideas. Special economic zone is a geographic concept. In order to attract the foreign capital, to settle foreign enterprises set up in the special region in term of law and other areas in the country government is establishing it. The special zone has the more liberal and more favorable characteristic and the conditions of economic development. Pakistan encourage foreign investment under the act of 1976 private foreign investment promotion and protection, in 1992 the economic reform in the promotion and protection act, to attract the foreign direct investment mainly concerned about reducing the operating cost, and reduce the approval process, improve investor convenience and investment protection, removal of regulatory barriers, allowing the public private partnership, and to strengthen coordination set a new investment policy, so foreign investor have great opportunity to invest in Gwadar.

All along, the Pakistani Navy through mutual visits, joint military exercises, fight against terrorism and other activities in the sea is an essential strategic partner, strategy for the implementation of the Indian Ocean. On the other hand China is going to help Pakistan to develop the Gwadar port, but also helping in the development of Pakistan's economy, deepening all the weather strategic partnership of cooperation between China and Pakistan.

The construction of China Pakistan Economic corridor, Gwadar is leading, industry is the protagonist. The Government of Pakistan has launched duty free Zone, established Special economic zone, for 20 years, to attract the foreign investment, expand economic and trade activities, especially welcome Chinese investment into the area of Gwadar.

Oil from west and imports or exports from Middle East, will be able to direct shipping through the port of Gwadar, through Pakistan, across from the Karakoram range and get into China. Therefore, China Pakistan economic corridor will become to help China to further break the important supplement force energy of Malacca dilemma. On the one hand this route from Middle East to China's energy transport line length relationship, the Gwadar port can make China's energy transport routes shortened $85 \%$ thus greatly reduce the risk of shipping, on the other hand China Pakistan have long friendly diplomatic relations, as the energy channels provides more stable diplomatic environment between both countries. Through this business model both countries can obtain the energy channel approach to maintain the national interests, but also to maintain the strategic balance in the region. Finally construction of China Pakistan economic Corridor will help promote cultural exchange between such as Iran, Afghanistan, India, Pakistan, China and other regional countries. 
The proposed oil and gas pipeline along with this project will solve the energy crises in Pakistan as well as in China. The Corridor can change the Iran Pakistan India pipeline into Iran Pakistan China gas pipeline (Irshad, 2015).

CPEC will bring Chinese technology, and expertise in his field of energy, irrigation, infrastructure development, agriculture, trade and commerce, communication. It will open new avenues for trade and business in the region.

The China Pakistan Economic Corridor is an alternative energy route to states like Azerbaijan, Kazakhstan, Turkmenistan and Uzbekistan. These countries are dependent on Russia for their oil and gas export through Black sea pipeline network. Russia is exploiting these countries by charging them above market prices for transportation to the world markets. The proposed corridor is an alternative route to these states (Irshad, 2015).

United States announced withdrawal from Afghanistan, But United States do not want abandon Afghanistan, has been working to maintain its regional dominance, even if the withdrawal, will try to continue to maintain its military influence there, so USA is seeking to establish strategic relations with India, to break the blockade restricting China's attempt be unity and cooperation with Pakistan. South and Central Asia has been the formation of active geo Political network. At the same time in its domestic economic development, strengthen the economic cooperation between Pakistan, Iran, Afghanistan, and Central Asian countries.

Construction of China Pakistan Economic corridor is pyretic abundance, for the development of China's export economy. Currently China imports 60\% oil from Middle East, 80\% of which must pass through the Strait of Malacca transported into China and the United States and Indian Navy controls the Strait of Malacca. China's oil transportation stuck into throat. Therefore, Gwadar is the best shortest alternative possible route.

\section{Imperatives for China and Pakistan}

Gwadar port will occupy an important position in CPEC. It will reduce the distance as compared with Malacca Strait route, it can provide shortest and safest route, it will not only transport the goods to China, but also will help foreign supplies. CPEC will reduce the distance if goods shipped from China to Pakistan. China Urumqi, via Shanghai to Gwadar distance is 15858 kilometers, but after the completion of CPEC distance will be reduced 4712 kilometers. CPEC will also reduce the distance from Dubai to Urumqi and London respectively, original 16833 kilometers and 27436 kilometers to 5772 kilometers and 16552 kilometers, thereby effectively saving time and cost.

In the list of projects in the economic corridor, the distribution of electric power construction projects in the different regions accounted for more than 1/3. Power shortage is serious problem faced by Pakistan. During the summer, electricity gap was up to $6500 \mathrm{MW}$. In rural areas load shedding is 14-20 hours every day, whether it is government office, think tanks office, schools, colleges, universities, hotels, will encounter many power outages. In energy projects including the IPP (Independent power plants) mode in construction $20000 \mathrm{MW}$ energy projects, power transmission lines, $1000 \mathrm{MW}$ of Bahawalpur solar Park project, $1320 \mathrm{MW}$ thermal power project 
on Qasim Port Karachi, and in Karachi 220 MW of solar renewable energy projects will help Pakistan to fight darkness.

This project will create millions of job opportunities for the region of local people, and it will carry out technology transfer. China and Pakistan both countries have strong political relations but do not have good relation in Economic and trade fields, Construction of this project will not only change the status quo and China will become the largest investor in Pakistan, but will also make more extensive region of Indian Ocean, Gwadar, and Central Asia, it will be integrated Central Asia and South Asia.

Gwadar port has an important role in the Pakistan's economic and social developmental. So far, still in Pakistan's economic and social development, Baluchistan is relatively backward area. In Pakistan Province's labor productivity, it is ranked four. It will help to Baluchistan province's economic and social development. Need to involve a lot of manpower in the construction and operation of port, which will generate local employment and will improve the social status of local people.

At present Pakistani markets, have been flooded with Chinese smuggled goods. In fact, smuggling normally takes place to save customs duties. The implementation of the (FTA) free Trade agreement can curb such activities. A positive impact on Pakistan's economy can take place if inflow of the commodities is documented. No doubt that due to FTA the inflow of various goods will increase, which can affect the local industry, particularly the country is having a weak economy. Therefore, objection was expressed by various sections of Pakistani society including, small businessman, industrialists of the country. Pakistan having a small economy as compared to China, Pakistan is unable to compete so it should be kept in mind the needs of Chinese local industries.

There is an opinion that the adoption of the FTA will be beneficial for the both countries, Pakistan will not only be getting benefits in shape of more investment, but will have access to huge Chinese markets to sell its products. In recent years, the average value of signed contracts of the labor services amounted about US\$ 500 million per year. By the end of September 20072008, the total value of contracted engineering and labor services cooperation projects of China in Pakistan amounted US\$ 8.64 billion and the turnover was US\$ 7.2 billion. By September 2007- 2008 the agreed investment of China in Pakistan was US\$ 110 million and the actual investment of Pakistan in China was more than US\$20 million (Hamid, 2012).

China has become the world largest consumer of energy. At the same time, China has become the world largest oil net importer. In 2013 BP statistics shows that China's external dependence on crude oil will be high $58 \%$, beyond the United State foreign dependence ratio is only $53 \%$. According to other relevant projects, degree of depth of Industrialization and urbanization, in 2020 China's oil demand will reach 4.5 tons to 6.1 tons. According to the international energy agency estimated that in 2025 China's crude oil external dependence will be reached up to $82 \%$. Mostly crude oil imports from Middle East and Africa the traditional oil producing regions. Through the Strait of Malacca into south China, distance is 3 times longer than Gwadar and is not safe, therefore China's energy security caused a huge risk, the formation of the so-called Straits predicament. Since through China Pakistan Economic corridor, it will provide new way to 
solve, straight crack Malacca dilemma, and Pakistan navy through visits, joint military drill, combating terrorism and other marine activities, maintain maritime cooperation.

Geo strategic location of the corridor will provide an opportunity to China to keep close surveillance over the Indian military activities in the India Ocean.

The crossroads of Pakistan in South Asia, Central Asia, the Middle East, have potential to become the trade and energy corridor in the region of countries. However, by the impact of situation in Afghanistan, Pakistan does not currently have become the complete access to Indian Ocean leading to Central Asia and Russia. In Future, China Pakistan Economic Corridor will help Pakistan to become future connected trade hub in the western region in China, Afghanistan, and other Central Asian countries. Construction of railway network and power lines will help Pakistan to realize the modernization of infrastructure, making it become a regional center of trade and commerce.

\section{Challenges/Barriers for China and Pakistan}

Pakistan has four provinces Punjab, Sindh, Baluchistan and Khyber Pakhtunkhwa. Each province is living with his own ethnic group majority, every ethnic group have difference language, culture, different living of style, and different nature. Lack of ethnic structure of the ethnic group is dominant overwhelmingly itself, and it is not conducive to the sense of formation of national identity, the religious groups claims the national identity on the basis of religious foundation. Security forces, Government of Pakistan, educational institutes have failed to effectively solve issues between different ethnic groups, because they are not agreeing with each other. Since there is no entanglement to which area will be first in the Pakistan, so the construction of corridor to reach a consensus is difficult. The national problem is most fundamental reason and Pakistan has no real national political party.

Baluchistan province as a big province in Pakistan's and abundant with natural resource, at the same time economy structure projects mineral resource, oil, gas have made a great contribution to the development of national economy, but the local people not only low in economic output, and no benefit to the province. Poverty rate increased 5\% as caretaker, so local people believe that the so-called development project of the previous federal government, in fact it is not benefit to the local people, but plunder their resources, for example construction of vast majority of highway in order to make the army more convenient to control local people. It is because of the strong dissatisfaction with the state of mind. Local people think that people of Punjab are more likely to rob us, exploitation is borrowing in the name of development.

In Baluchistan Province, nationalist rebels launch the explosive terrorist attacks if government starts the economic projects, specifically railway, oil and gas pipelines and transmission facilities are the key targets of attacks and don't let it flow to the other provinces specially Punjab.

The $18^{\text {th }}$ Amendment in the Constitution 1973 has transferred all powers to provinces which have become more autonomous in their respective areas. A consensus is necessary for the construction corridor. Both Baluchistan and Khyber Pakhtunkhwa have reservations over the proposed new route of the corridor which may endanger the construction of the project. A bad law and order situation in these provinces is another hindrance for the smooth functioning of the 
corridor, lack of infrastructure in both provinces because of their mountains terrain which is big challenge (Gul, 2015).

Russian wants status quo as for as the construction of new pipeline in the Caspian region is concerned. It has monopoly over the existing route from Caspian to Europe and beyond. The construction of new pipelines will challenge its monopoly. Russia will try its level best to stop the construction of China Pakistan Economic Corridor. The corridor also raised alarm bells in India, US and Europe as it will enable China fulfill its strategic interests in the Indian Ocean which will be easily available after the completion of corridor. Some experts in the US have referred to China's cooperation in the corridor as China's string of pearls strategy which refers to China's lines of communication in sea (SLOCs) (Siddiqui, 2015).

Since China Pakistan Economic corridor is so important so United State will not sit idly. Pakistan has low level of democratic and political integrity, which is paradise for the United State to intervene in the internal affairs, which dragged Pakistan into mire. Americans with its dominance of the dollar and the media hegemony, simply folkway money in society, put a lot of negative information about CPEC. Provide secrete fund to militants through the multinational funds to finance armed groups and individuals, directed as a target CPEC.

Gwadar port has become a key transportation terminal. The global strategy of United States cannot be ignored the pearl of Gwadar port. In 90 s of the $20^{\text {th }}$ century, Americans planned to start oil pipeline from Turkmenistan as a starting point, through Afghanistan, extended to Gwadar, later on program influenced by Russia. The reason is that Russia preemptive purchase $80 \%$ of oil and gas from Turkmenistan, resulting Turkmenistan do not have sufficient supply of crude oil for this pipeline. So later, United State was not interested in Gwadar. In 1998, United States again coveted Gwadar. Agreement was almost done between both parties, American Businessman and Local Government of Gwadar. The agreement provides all control of port, including infrastructure and enjoyment of the right to take security measures to United State. That time Pakistan military and media have much dissatisfaction, and ultimately failed to sign the agreement, and United State directly failed to intervene in Gwadar port. Cooperation and development of Gwadar is led to Ocean, and America does not want monitoring by China. So, may Unites State will try to create barriers.

During the Construction process of CPEC, the problems of security issues are difficult to ignore. The current anti-terrorism situation in Pakistan is still grim. In this year major incident of terrorism related violence in Pakistan, from January to 12 August, 289 civilian died, 87 Security Force Personnel, 591 Terrorist died and 667 injured (SATP, 2016). South Asia is terrorism rampant. After the withdrawal of United States from Afghanistan the political movement and Pakistan security situation is worrying.

\section{Recommendations}

China Pakistan Economic Corridor will be benefited for the whole Pakistan, even local ruling party insisted on the priority to first start project in their own region, but it will not influence the dividend of economic corridor for the nation. 
Some militants will try to create problems, undermine the project but government of Pakistan stressed that they are doing utmost to ensure the safety of foreign investor, for this purpose military trained 10000 soldiers to protect the local Chinese, and government of Pakistan should promote training institutes there, the local people have limited skills so can only be engaged in low cost office, coolies, auxiliary work.

Gwadar port development will drive traffic road network, lack of infrastructure in Baluchistan will generate traffic problem and traffic jam. The Pakistani government should plan now how to deal with it and modernization railway system is also imperative there.

Gwadar port is just 400 kilometers from Strait of Hormuz, guarded by gulf oil channel. Gwadar has potential to become the Indian Ocean and gas resources processing center, oil transportation, storage, and large oil refinery. Through the Gwadar port can attract crude oil to the processing refine and re-export and shipped to Pakistan domestic consumer market, it will alleviate the shortage of domestic energy.

For the plight of Pakistan is facing many difficulties, China should promptly lend a helping hand, to learn and exchange the knowledge of youth between two countries, enhance understanding in the cultural level. Economic and trade exchanges between the two side to the people of both countries to bring real benefits, especially Pakistan Economic corridor opened overall framework of the future and recent result can foresee optimism. The prospects for cooperation between the two countries in the field of economic and trade very optimistic, Pakistan relation will not Change, based on the strong bilateral Cultural exchange will make further cooperation in economy and other areas of mutual complement each other.

Pakistan should strengthen the laws to control smuggling between both countries, Pakistan should maintain law and order and improve its security conditions in order to attract Chinese investor, and Visa facilities should be provided to encourage people relation which is necessary instrument to enhance trade and business.

\section{Conclusion}

Stability of Pakistan and development of China Pakistan Economic Corridor are closely related. At present, China Pakistan Economic Corridor is blessing for Pakistan and for the regional countries in the area. For economic benefit, should avoid to loss this project. There are many problems are difficult to solve, lack of economic hinterland, connected economic zone development is not ideal, infrastructure is not enough, traffic resource and roads are limited, armed attacks have occurred time to time, all these factors are not conducive to promote the construction of China Pakistan Economic corridor. Gwadar port is long term project, need to repair equipment, maintain, update, pay attention on basic necessities of life, including clean water, hospitals, schools, public facilities, and surviving of electricity of shortage, focus on the development of economic science and sustainable development. In short the strategic value of this project is far reaching, development should be gradual, need more patience, concentration, seriously deal with difficulties, challenges and foresight. During the study, the future development between both countries most scholars are more concerned about is pressure from the United States, and the western world, impact of the trend of Pakistani religious and ethnic extremism, threats from India, Afghan Taliban, the relation between Pakistan and India, Impact 
of China and India Relationship, domestic situation in Pakistan, long term instability and so on. As the above can become important factor restricting the development of China Pakistan Economic Corridor. In my opinion the above factors are not certain, but all these factors are controllable, adjustable, and can be avoided, and the real constraint on the development of China Pakistan Economic corridor between the two countries. China Pakistan Economic corridor is an integral part of China's connectivity between Asia, Europe, and Africa, this vision is the new face of Chinese diplomacy as it is in line with the purpose and principles of United Nations (UN) Charter and based on five principle of peaceful co-existence. This vision is inclusive in nature, tolerant, in character and seeks common development and prosperity. Pakistan is proud to be part of this vision.

\section{References}

Gul, I. (2015). Pakistan China cconomic corridor. The Express Tribune. Retrieved from https://tribune.com.pk/story/854706/pakistan-china-and-the-economic-corridor/

Hamid, N. (2012). The opportunites and pitfalls of Pakistan trade with Chian and other neighbors. The Lahore Jounral of Economic, 2(5), 135-145.

Irshad, M. S., Xin, Q., \& Arshad, H. (2015). One belt and one road: Does China-Pakistan economic corridor benefit for Pakistan's economy? Journal of Economics and Sustainable Development, 6(24), 200-207.

Rafiq, A. (2016, October). CPEC \& related projects: CPEC projects. Paper presented at the International Academica Symposium on China-Pakistan Economic Corridor, Beijing, China.

Raza, S. I. (2013). China given contract to operate Gwadar port. Dawn. Retrieved from https://www.dawn.com/news/786992

SATP. (2016). Major incidents of terrorism-related violence in Pakistan. SATP. Retrieved from http://www.satp.org/satporgtp/countries/pakistan/database/majorincidents2016.htm

Siddiqui, S. (2015, March). Gawadar China string of pearls, ICWA. Paper presented at Indian Council World Affairs International Conference, Karachi, Pakistan. 